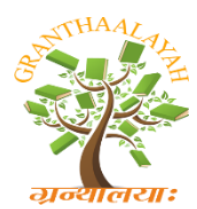

\author{
INTERNATIONAL JOURNAL OF RE
GRANTHAALAYAH \\ A knowledge Repository
}

Science

\title{
IMPORTANCE OF RESEARCH AND DRAFTING IN THE SCIENTIFIC PRODUCTION OF THE HEALTH AREA
}

\author{
MGS. Alida Vallejo ${ }^{* 1}$, MGS. Marjorie Ramirez ${ }^{2}$, MGS. Ingrid Gurumendi ${ }^{3}$, LCDA. \\ Tania Perdomo ${ }^{4}$ \\ 1,2,3,4 Faculty of Medical Sciences, University of Guayaquil, Guayaquil, Ecuador
}

\begin{abstract}
Research increases human knowledge and enriches science, generating progress, quality of life, health, innovation, hence the importance of promoting it at all educational levels. Higher education institutions must implement the necessary strategies to improve communication skills, especially to improve the way of writing in order to share with the public the scientific findings that are inherent in the area of health in particular and of all science in general. The objective is to promote research to increase the production of scientific articles, with the socialization of knowledge in the area of health. Several factors influence this process. Scientific writing must complement the strengthening and interest of research, the publication of the results of the studies carried out must be shared with the entire society to benefit it and increase scientific production.
\end{abstract}

Keywords: Research; Teacher; Student; Higher Education.

Cite This Article: Alida Vallejo, Marjorie Ramirez, Ingrid Gurumendi, and Tania Perdomo. (2020). "IMPORTANCE OF RESEARCH AND DRAFTING IN THE SCIENTIFIC PRODUCTION OF THE HEALTH AREA." International Journal of Research Granthaalayah, 8(1), 83-89. https://doi.org/10.29121/granthaalayah.v8.i1.2020.251.

\section{Introduction}

\subsection{Importance of Research and Drafting in the Scientific Production of the Health Area}

From prehistory men communicated orally, they had no writings, but beyond that he felt the need to leave a mark, the first inscriptions were carved in rocks, the so-called pictograms remained there, as a sign that there was an attempt to Humans to leave a record of their presence, for future generations, those messages are an important legacy, heritage of society.

The first book written is a story of the Chaldean flood, made on a clay tablet with approximately 4000 b. C. Around the year 2000 b. C. A medium made from the papyrus plant was used, forming a roll of approximately 60 to $120 \mathrm{~cm}$ attached to a wooden cylinder. In 190 a. C., the Greeks made animal fur rolls and assembled large libraries in Ephesus and Pergamos (Middle East) and Alexandria. 
However, the invention that marked humanity was the role that the Chinese played in the year 105 of our era. Later, the printing press was invented, with which they began to write, and this event changed history because the new intellectual era began where the first printed book was the Bible in lines and which would then be printed would be very popular. Gradually, write and became the way to capture stories, long or short stories, thoughts and save important information, a way to communicate without the need for participants to be present.

But how important it is to preserve this information would be the way of writing it, without a doubt this aspect is very relevant, because the details, the style, the clarity, the way of doing it, play a fundamental role in a writing, really writing is an art , for not doing it in the right and proper way, valuable information would be lost that could be crucial for the transition of the information, of the consent, of the history, of the recipe or of the intention with which the information was initially thought from the author perspective.

Within this approach, in the area of health and in all areas, research is considered to contribute in some way to knowledge should be socialized with the community in general and the only way to do so is through a publication. There is so much information that is changing minute by minute.

New possibilities arise every day to treat a health problem, diseases are discovered, or existing ones are analyzed from another perspective.

A health professional must contribute in one way or another with scientific information.

Research is considered an activity aimed at obtaining significant findings that increase human knowledge and enrich science. It has the ability to favor the development of skills and the discovery of new facts, according to advances in technique, technology and thinking (Bijarro, Francisco 2007).

Research plays an important role in the training process of future medical professionals since the first time they work, because the area of medicine constantly updates the most optimal knowledge, methodologies and procedures and allows improving the quality of medical processes of attention. Research arises when there is curiosity and desire to know a specific topic, also when we ask questions about how things work, about the impact caused by people's behavior, the effect of a natural phenomenon and even improve the results of others. investigation.

In the new educational context, research is considered one of the most feasible means to promote self-learning and improve problem-solving skills. The university is the best place to promote scientific activity, since it allows the cloister to keep in touch with the international flow of knowledge, through internationalization processes. This route allows enriching productive systems, obtaining updated information and attracting financial resources, as well as establishing scientific projects with greater risk and potential profitability (Núñez and Montalvo, 2014).

In 1665 it is estimated that they published the first scientific journals that came from France and England, becoming a very important means of communication in the sciences. Around 70,000 scientific articles are published today. (MCKERROW) 


\section{General Objective}

Promote research to increase the production of scientific articles that have added value and promote the socialization of knowledge in the area of health.

\section{Methodology}

We consult bibliographic sources in specialized journals of Latindex, Scielo, Redalyc and review articles, to obtain data on the subject that will be used to draw conclusions and recommendations.

\section{Developing}

During a learning process, an investigation must be carried out that can lead students to produce new knowledge, which in turn must be transmitted to other people, through article publications, after an objective and coherent writing. Problems occur more and more frequently when language is used incorrectly, with bad diction habits and bad spelling, especially due to social networks.

Universities should promote the interest of researchers in the communication of science, as well as promote citizen participation in knowledge management processes, their applications, scope, risks and uncertainties; For this, it must encourage the acquisition of new skills in research staff (...) This is a challenge that must be assumed wisely, to reflect that knowledge and science must be informed to society. (Castle A, s / f.)

Scientific texts are of great importance since writing makes it work in an intellectual field to be able to transmit the message to the reader correctly. The writing of a text allows to know the previous results since the content is clearly synthesized. Research and systematization are the key elements of this research because thanks to them there is a structure that maintains coherence and order.

The main objective of scientific writing is to communicate the expected results of a scientific investigation, which is of maximum comprehension for the reader and to obtain a cautious way of informing the findings achieved with efficiency and skill, it is then for a greater intellect of scientific research. It is essential to master the basic aspects of scientific writing that are precision, clarity and brevity. Precision is obtained when there is accuracy and ideas are explicitly expressed. Clarity is very important for scientific writing because a clear and direct message makes research ideas flow, but if ideas are not clearly expressed, the reader will not give importance to research. In addition, the author must leave redundancy and unnecessary talk for the expression of information. (Delgado-Ponce, 2016).

The training of researchers in education in Latin America is preceded by the development of disciplinary fields that address education as its object of study (...) the current state of educational research in the countries of the region has to face the changes that generate various new studies and scientific contributions. (Rincon, C 2011).

Scientific writing is a skill that is learned and perfected with time and practice. To understand an investigation, you must first have a clear perspective of what you are trying to say. From 
prehistory, our ancestors communicated orally until, as the years arose and today, scientific contributions emerged to instruct people. Already Hippocrates, he knew the importance of documenting all the procedures and symptoms that appeared in his patients, he could still record what should be done to preserve or improve health, if he and many others had not developed the ability to write today, no. I know many scientific achievements.

Scientific writing is fundamental in the field of research, since it seeks to reach the recipient in the most exact way, transmit the message in a few words, which is something simple, clear and orderly. In order to provide the reader with the clear content of an investigation, in addition to being one of the most important aspects for the acceptance and publication of an article, magazines, etc.

The United Nations Educational, Scientific and Cultural Organization (UNESCO, 2013) revealed that China, the European Union, Japan, the Russian Federation and the United States. they still represent $72 \%$ of the research population in the world. While in Latin America and South Asia, $8 \%$ and $23.3 \%$ of the world's population of researchers are concentrated, the approximate mode is: $3.6 \%$ in the first and $3.1 \%$ in the second, which represents a decline Researcher rate.

In 2017, Ecuador ranked 66 (among 230 countries) in the world production of scientific articles, the analysis of this production reflects that between 15 and 20 percent of this production is unreal, since it comes from partnerships with other countries, therefore, owns Production is low. With respect to publications, in Ecuador, more than $80 \%$ of Ecuadorian publications include international collaboration, mainly with the United States, Spain, United Kingdom, Germany, France, Brazil and Colombia. This phenomenon is known by almost all Ecuadorian researchers and determines that national scientific production is limited.

Currently and according to the data of the World Intellectual Property Organization (WIPO or WIPO according to its acronym in English) of 2018 and early 2019, Ecuador occupies the ninth and eighth place in the ranking of the Global Innovation Index 2019, ranking that It brings together the exhibitors with the highest level of research and scientific development.

These problems of low scientific production are probably due to several factors and one of them could be that most people cannot capture what they find in their results when they investigate. Apparently, people have not given importance to the development of communication skills, especially when writing or writing new discoveries after an investigation.

It is necessary to promote the interest of the whole society, starting from the first years of study, generating a culture of researchers who can write their work with ease, eloquence and coherence, being the authorities who should increase interest with programs and training courses in writing.

All research must be published and for this it is very important to mention that the researcher must present his work in written form, for the socialization of knowledge. The correct use of grammar and punctuation marks are the key to good writing, writing in detail, following a logical line and giving coherence is essential to be able to communicate on a research topic. It also improves the lexicon by recognizing medical terminology and increases the cognitive process by ordering information, analyzing it, synthesizing it and expressing it in writing. 
Writing is not only writing, it is doing it correctly and it also follows ethical guidelines, which require good practices around scientific publication, a scientific writing is the result of the preparation of a work based on the results obtained from the effort and dedication. All this also recalls the importance of strengthening good language during the period of training of students, to transmit the research correctly and that meets the author's communicative intention. It is important to consider Roslyn Petlyn's phrase "Nothing can make you lose credibility faster and seem ignorant than a writing error."

It is urgent, then, to promote research as a resource for the autonomous production of knowledge, which depends not only on the creation of individual and group experience and learning, but also on the efficient management and organization of research processes. Padrón, J. 2007

Then, it must raise awareness about the great importance of promoting the socialization of knowledge through scientific writing, in a process that goes hand in hand with the strengthening of the appropriate use of language and that is a fundamental pillar of the prestige of a professional in in accordance with current trends to investigate and contribute to the science of scientific production.

\section{Conclusion}

Scientific research in health sciences is an important pillar in the development of professionals, since all knowledge must be socialized through writing, and it contributes to increasing scientific production.

It is imperative to strengthen communication skills in the academic field to socialize the results of an investigation, for this an appropriate terminology must be used, as it demonstrates its preparation during the academic training process.

The grammar rules are decisive to fulfill the author's communicative intention when making a scientific writing. A good writing projects the image of a professional of quality in all the areas, allows to socialize the information of suitable way, so much when presenting reports, the investigation through the writing and publication of scientific articles.

The entire university community must be aware of the importance of strengthening the research culture, as it is a factor that affects the development of countries in the social, economic, scientific and especially in the area of health.

\section{References}

[1] Anonimo. (27 de Mayo de 2011). Coyuntura economica. Recuperado el 19 de Agosto de 2019, de https://coyunturaeconomica.com/comunicacion/redaccion-administrativa

[2] Carmen Isabel Padrón Novales1, N. Q. (03 de 2014). Aspectos importantes de la redacción científica. Recuperado el 18 de 08 de 2019, de http://scielo.sld.cu/scielo.php?script=sci_arttext\&pid=S1561-31942014000200020

[3] Delgado-Ponce, Á. (6 de 05 de 2016). Redacción científica: precisión, claridad y brevedad. Obtenido de https://comunicarautores.com/2016/05/06/redaccion-cientifica-precision-claridad-ybrevedad 
[4] Escalona, K. (2016). Ortografía.com-es. Recuperado el 19 de Agosto de 2019, de https://ortografia.com.es/redaccion-academica/

[5] Eusebio V. Llácer Llorca. (s.f.). EL LENGUAJE CIENTÍFICO, LA DIVULGACIÓN. Recuperado el 19 de 08 de 2019, de https://www.uv.es/ferbaro/papers/lenguaje.pdf

[6] MCKERROW, R. B. (s.f.). ¿Qué es la redacción científica? Recuperado el 18 de 09 de 2019, de http://proyectos.javerianacali.edu.co/cursos_virtuales/escritura_articulos_cientificos/lecturas/mod ulo2/unidad2.1/la\%20redaccion\%20cientifica.pdf

[7] Symautomatizacion. (5 de Mayo de 2016). slideshare . Recuperado el 19 de Agosto de 2019, de https://es.slideshare.net/symautomatizacion/redaccion-literaria

[8] Gutiérrez Escobar, M., \& López Fernández, R., \& Sánchez Ortiz, L., \& Yanes Seijo, R., \& Rodríguez Arencibia, R., \& Molina Gómez, A. (2009). Curso a distancia para la redacción de artículos científicos. MediSur, 7 (2), 12-17. De http://www.redalyc.org/pdf/1800/180014821002.pdf

[9] Bijarro, Francisco (2007): "Desarrollo estratégico para la investigación científica", Cancún, <www.eumed.net/libros-gratis/2007c/306/306.zip> [15/08/2016].

[10] Castillo Vargas Andrés Dr. Importancia de la divulgación en la comunicación científica académica Instituto de Investigaciones Psicológicas Escuela de Psicología Universidad de Costa Rica http://www.ebci.ucr.ac.cr/sites/default/files/descargables/castillo_vargas_andres_importancia_de_ la_divulgacion_en_la_comunicacion_cientifica_academica.pdf

[11] González Argotea Javier, Alexis Alejandro García-Rivero B y Alberto Juan Dorta-Contreras Articulo Original Producción Científica Estudiantil en Revistas Médicas Cubanas 1995-2014. Universidad Nacional Autónoma de México, Facultad de Medicina Disponible en Internet 2 de marzo de 2016 Inv Ed. Med.2016;5(19):155-163.

[12] González Óscar J Alcántara 2010 La Responsabilidad Social en Las Universidades Españolas Editor Dr. D. Óscar J. González Alcántara, Dr. D. Ignacio Fontaneda González, Dr. D. Miguel Ángel Camino López, Da. Araceli Antón Lara

[13] GOMEZ, J. ; DIEGUEZ, P.; GOMEZ 2014 Motivando el interés por la investigación científica en estudiantes de educación media superior Congreso Iberoamericano de Ciencia, Tecnología, Innovación y Educación D ISBN: 978-84-7666-210-6 - Artículo 353 Buenos Aires Argentina Benemérita Universidad Autónoma de Puebla. México.

[14] Juárez Rolando Pablo Alejandro Profesor Titular. Cátedra Fisiología Humana. FOUNNE Reflexiones sobre la Cultura Científica y Tecnológica desde el enfoque CTS. Revista Facultad de Odontología ISSN No 1668-7280 | Opinión | Vol. IV | No 1 | 2011.

[15] Mazuera Arias, Rina, La investigación y las revistas científicas. Revista Virtual Universidad Católica del Norte [en linea] 2016, (Febrero-Mayo) : [Fecha de consulta: 8 de agosto de 2019] Disponible en:<http://qwww.redalyc.org/articulo.oa?id=194244221001> ISSN 0124-5821

[16] Medina, D. E. M., \& Morales, N. A. (2014). Importancia del cambio generacional para el desarrollo de la ciencia y la tecnología en México. Hitos de ciencias económico administrativas, (50), 35-40.

[17] Molina, Ó. D. (2015). La transferencia de conocimiento científico y tecnológico: un reto que deben afrontar las universidades. Portal de la Ciencia, 8, 9-15.

[18] Morales, P. (2010). INVESTIGACIÓN E INNOVACIÓN EDUCATIVA. REICE. Revista Iberoamericana sobre Calidad, Eficacia y Cambio en Educación, 8 (2), 47-73. https://www.redalyc.org/pdf/551/55114080004.pdf

[19] Norero V., Colomba. (2000). Medicina y ciencia: una relación indispensable. Revista chilena de pediatría, 71(2), 81-82.

https://dx.doi.org/10.4067/S0370-41062000000200001

https://scielo.conicyt.cl/scielo.php?script=sci_arttext\&pid=S0370-41062000000200001

[20] Padrón, J. 2007. Tendencias epistemológicas de la investigación científica en el Siglo XXI. Cinta de Moebio: Revista de Epistemología de Ciencias Sociales

[21] Cinta moebio 28: 1-28 PDF VENEZUELA. http://www.moebio.uchile.cl/28/padron.html 
[22] Rincón Ramírez Carlos LA FORMACIÓN DE INVESTIGADORES EN EDUCACIÓN: RETOS Y PERSPECTIVAS PARA AMÉRICA LATINA EN EL SIGLO XXI Universidad Autónoma de Chiapas, Revista Iberoamericana de Educación (ISSN: 1681-5653) México

[23] Para Rodríguez-Santana 2012 El Modelo de Futuro de Gestión de la Salud, opuestas Para Un Debate Editorial Visión Libros, Ignacio Para Rodríguez-Santana

[24] Ruiz Juan Carlos, M. (s.f.). LA INVESTIGACIÓN CIENTÍFICA EN EL ECUADOR. Mèdicina Crítica, II(2). Obtenido de

http://www.medicosecuador.com/medicina_critica/rev_vol2_num2/la_investigaciona.html

*Corresponding author.

E-mail address: alida.vallejol@ug.edu.ed ositos_3@yahoo.es/mayito.ramirez25@gmail.com 